\title{
It's Not Just Structural: Social Movements are not Homogenous Responses to Structural Features, but Networks shaped by Organisational Strategies and Status
}

\author{
by Clare Saunders \\ University of Southampton \\ Sociological Research Online, Volume 14, Issue 1, \\ < http://uww. socresonline.org.uk/14/1/4.html> \\ doi:10.5153/sro. 1856
}

Received: 21 Jul 2008 Accepted: 16 Jan 2009 Published: 31 Jan 2009

\begin{abstract}
Political opportunity structures are often used to explain differences in the characteristics of movements in different countries on the basis of the national polity in which they exist. However, the approach has a number of weaknesses that are outlined in this article. The article especially stresses the fact that such broad-brush approaches to political opportunity structures fail to account for the different characteristics of movement organisations within the same polity. The article therefore recommends using a more fine-tuned approach to political opportunities, taking into account that the strategies and status of organisations affect the real political opportunities they face. This fine-tuned approach is used to predict how the status and strategy of environmental organisations might influence the extent to which different types of environmental organisations in the UK network with one-another. We find that organisations that face an open polity those with a moderate action repertoire and a constructive relationship with government institutions - tend not to cooperate with those with a radical action repertoire and negative relations with government institutions. On the other hand, those that vary their action repertoires, and which have variable status according to the issues involved or campaign targets, have a much broader range of network links with other types of organisations. Thus, there is much more diversity in types of environmental organisation in the UK than the broad-brush to political opportunity structures would account for. Nonetheless, it does seem that environmental organisations are aware of how their own behaviours might influence (nonstructural) political opportunities, and that they mould their strategies and networking patterns around this awareness.
\end{abstract}

\section{Keywords: Environmental Movement, Political Opportunity Structures, Social Movements, Social Networks}

\section{Introduction}

1.1 Social movements are most commonly understood to be semi- or non-institutionalised networks of activists and organisations that share a common identity and engage in collective action against a shared opponent (Diani 1992). Whilst movements are frequently, if not ubiquitously, defined as networks, social movement theory often fails to explain why organisations and activists within the same movement network adopt different strategies, have variable status with the polity, and consequently network with one another to varying degrees. Scholars such as Offe, Touraine and Melucci, for example, have argued that the emergence and behaviour of new social movements can be attributed to the 'structure' of 'modern' societies (see Lentin 2001). Similarly, Kriesi (1995), Kitschelt and other political process theorists argue that social movement strategies are determined by the characteristics of the national polity within which they operate.

1.2 Such theorists tend to imply that movements within a particular state are homogenous entities - that organisations and activists working within a given set of structural conditions behave similarly. However, it is a given fact that movement organisations within the same movement often have a variety of aims, structures and strategies. For example, animal rights activists include 'hard core vegans' and those who argue that 'you don't have to give up meat to care' (see Walls 2002 on the Campaign Against Live Exports in the UK). This has two important implications for social movement theory: firstly, that broad-brush approaches to theory gloss over the differences between organisations and activists within movements, and secondly, that it is not feasible to rely on macro structural features of a polity as predictors of the overall 'extent to which decision-making is accessible' (Lentin 2001:3.1). Decision-making procedures will probably always be more open to moderate groups than their more radical counterparts. 
broad-brush theoretical approach. Consideration of strategies and the status of organisations demonstrates that a more fine-tuned approach is needed to frame and investigate how political opportunities shape movements. As will be illustrated in this article, strategies and status affect the shape and form of networking between organisations within a movement.

1.4 The article begins by critiquing cross-national comparisons of political opportunity structures, which are generally too broad to account for the variation in types of organisations within social movements. After this critique, we will turn to look at the results of a survey of 141 environmental organisations within the environmental movement to consider whether their choices of strategies and their relationships with local and national government impact upon their networking.

1.5In doing so, the article also flags up another weakness of broad-brush approaches to political opportunity structures: they assume that all campaigns are directed towards policy change at the national level. The targets of social movements may be considerably more multifarious than this. Other targets, for example, include international financial institutions, corporations, and local governance. Whilst this article does not, for space reasons, address all possible targets, it does at least consider the latter.

1.6We hypothesise that those environmental organisations that use insider strategies and have a constructive relationship with the polity, at whichever level, will be unwilling to behave in a way that would jeopardise that relationship. This means that they are unlikely to collaborate in campaigns with outsiders radicals, or the under-resourced - which have no relationship to the polity. Organisations that use a range of insider and outsider strategies and consequently have a contingent relationship with governance are expected to have the broadest range of ties through being thresholders, which, by nature, sometimes work inside government circles and sometimes outside of them. Looking at the impact of strategy on political opportunities through the lens of interorganisational networking allows us to focus on a key movement dynamic whilst demonstrating the need for a more refined model for researching political opportunity structures.

\section{A Critique of Broad Brush Approaches to Political Opportunity Structures}

2.1 The political opportunity structure approach to social movements is constructed around the notion that the political environment affects the emergence, strategy, form and success of social movements. Although it has precedents in the collective behaviour approach, and Lipsky (1970) suggested that fluctuations in political systems should be considered when explaining protest, it was a concept by most accounts coined and christened by Eisinger (1973 - in Tarrow 1998, McAdam 1982 and Burstein et al 1995) who defined it as 'the openings, weak spots, barriers and resources of the political system itself. Much ground was made exploring the concept cross-nationally in the 1980s. However, different scholars have adopted an idiosyncratic approach to application of the theory, sometimes adding new variables fitting to the particular movement or polity under study.

2.2 In one of its more recent articulations, 'political opportunity structures' was referred to as the 'openness' or 'closedness' of the political context of the national polity in which social movements mobilise. According to Diani and Eyerman (1992:4-12) it refers to the presence or absence of political alliances, divisions within the elite, tolerance of the polity to protest, and the policy-making capacity of the state. The Diani and Eyerman definition provides a good example of a confused notion of what constitutes a political opportunity structure (cf Goodwin and Jasper 1999, 2003). In fact, as Rootes (1998) convincingly argues, none of these variables are structural in nature - they are temporary and volatile. Permanent characteristics of political institutional structure are what truly constitute a political opportunity structure, such as the nature of governmental institutions - especially their degree of centralization, and the way power is configured (the nature of the electoral system). Contingent, or non-structural, political opportunities are those that occur under the conditions mentioned by Diani and Eyerman (1992), with the addition of the degree of electoral stability.

2.3 Based upon structural and contingent types of political opportunities, it is possible, although not unproblematic, to conceptualise idealised 'open' and 'closed' polities (Table 1). Even though they are usually treated as if they can be neatly slotted into one category or the other, real life polities always fall someway between these two extreme types. Idealised 'open' states have a decentralised structure, egalitarian ideology and proportional representation - allowing informal and formal access; thereby absorbing pressure before it builds up, resulting in moderate social movements. In this kind of polity it is assumed that social movement activists regard negotiations and demonstrations as worthwhile as they will be likely to result in policy gains. As Kitschelt (1986:302) sums up, those movements in a liberal egalitarian political culture are expected to be much less antagonistic, largely because they have less need to antagonise. By contrast, closed states - which at the extreme are centralised, corrupt and totalitarian - deny access, and activists regard conventional forms of political participation as time-wasting activities. According to this approach, when protest does occur in a closed polity, it tends to sway towards 'more direct forms of struggle such as land occupation, factory seizures, store-house raids and insurrections' (Bordreau 1996:181) or go underground and be violent and sect-like. A closed polity is most likely to engage in repression of social movement efforts. Heavy-handed policing and repression act as double-edged swords for social movements. 
For obvious reasons, they discourage social movement activity by increasing the costs for individual activists, yet could also serve as a stimulant to protest by reinforcing the identity, solidarity and sense of injustice that movements possess (Kriesi 1995:177-178, della Porta and Fillieule 2004:233). Della Porta (1995:80) sees protest policing as 'an important barometer of the political opportunities available for social movements'. Although perhaps over-generalising, she suggests that tolerant policing leads to diffuse movements, but harsh policing to smaller, more radical groups inclined to violence.

Table 1. Idealised Open and Closed Polities

\begin{tabular}{|c|c|c|c|}
\hline $\begin{array}{l}\text { TYPE OF } \\
\text { POLITICAL }\end{array}$ & $\begin{array}{l}\text { INDICATOR OF } \\
\text { OPENNESS }\end{array}$ & $\begin{array}{l}\text { DEALIZED } \\
\text { OPEN POLITY }\end{array}$ & $\begin{array}{c}\text { DEALIZED } \\
\text { CLOSED }\end{array}$ \\
\hline $\begin{array}{l}\text { STRUCTURAL / } \\
\text { PERMANENT }\end{array}$ & $\begin{array}{l}\text { Degree of } \\
\text { centralization } \\
\text { Configuration of power }\end{array}$ & $\begin{array}{l}+ \text { Decentralized } \\
+ \text { Proportional } \\
\text { Representation }\end{array}$ & $\begin{array}{l}+ \text { Centralized } \\
+ \text { Totalitarian }\end{array}$ \\
\hline $\begin{array}{l}\text { CONTINGENT / } \\
\text { TEMPORARY(ranked } \\
\text { in order of durability) }\end{array}$ & $\begin{array}{l}\text { Political culture } \\
\text { Policy making capacity } \\
\text { Elite divisions } \\
\text { Electoral stability } \\
\text { Policing / tolerance of } \\
\text { protest } \\
\text { Alliances and counter- } \\
\text { movements }\end{array}$ & $\begin{array}{l}+ \text { Egalitarian } \\
+ \text { Strong } \\
+ \text { Divided } \\
+ \text { Unstable } \\
+ \text { Tolerant } \\
+ \text { Elite Alliances }\end{array}$ & $\begin{array}{l}\text { + Corrupt / } \\
\text { inegalitarian } \\
\text { + Weak } \\
\text { + Undivided } \\
+ \text { Stable } \\
+ \text { Repressive } \\
+ \text { No Alliances }\end{array}$ \\
\hline
\end{tabular}

2.4 The contingent/temporary features of a polity are less stable and vary over time, but still impact upon the actual opportunities social movement organisations receive. Tarrow (1983 in Burstein et al 1995:288) suggests that movements are more likely to be successful in gaining acceptance, or making material gains (Gamson 1975) when a political regime is unstable, or has elite divisions. When a government and shadow government are in close competition, they are more likely to support the demands of social movements in an attempt to sway public demand in their favour (Maguire 1995).

2.5 Using ideas similar to those presented in Table 1, Kitschelt (1986) compared anti-nuclear movement protests in four Western liberal democracies, explaining the variation in tactics and acceptance of the movements according to polity receptiveness and output capacity. Similarly, Kriesi (1995:177-198) used measures of openness resulting in the ranking of Switzerland, Germany, the Netherlands and France in that order - from most to least 'open'. The different criteria of openness used by Kitschelt and Kriesi led to them producing strikingly different conceptions of the openness of the Germany polity. Kitschelt (1986:66) described the German polity as 'closed' because of its 'input structures' - having a centripetal party system and weak legislature - and 'output structures' - characterised by 'jurisdictional and territorial fragmentation of the state', an autonomous judiciary and little control over the private sector. Kriesi, however, on the basis of more structural characteristics - such as Germany's decentralised federal system that has points of access - classified it, perhaps more accurately, as open. Perhaps Kitschelt's interpretation was coloured by realisation that German anti-nuclear organisations lacked access? However, a more convincing explanation for German anti-nuclear organisations' lack of access to the polity might have simply been the movement's system-challenging ideology and strategies - a contingent rather than structural factor.

2.6 Furthermore, as Welsh (2001) strongly argues, not all organisations within the anti-nuclear movement in a particular country will share ideology and strategies. Welsh bemoans that the British anti-nuclear movement is often misrepresented 'as if it corresponds with an actual, undifferentiated collective actor' (Welsh 2001: paragraph 2.1). In actual fact, the British anti-nuclear movement, despite existing within a constant political structure, was historically split over both tactics and strategy. Whereas one faction focused on constitutional means of opposing nuclear energy, another turned towards education and direct action (ibid, paragraph 3.3). Thus, theories of macro-political opportunity structures neglect that different factions or even different organisations have varying behaviour that in turn influences strategies and status. As Rootes (1997:93) suggests '[political opportunity] systems may be relatively open or closed to different kinds of issues and or groups, and this makes global categorisation hazardous if not entirely arbitrary'.

2.7 Further, political opportunity structure theory assumes that all movements depend on, or target, national 
political institutions to the same extent (Meyer and Staggenborg 1996:134). In reality, sub- and countercultural movements are likely to have more autonomous targets and be considerably less affected than those instrumentally oriented organisations or movements with a 'highly focused problem structure' (Kriesi 1995:193). What curtails one type of movement (for example a closed policy window) may be exactly the feature that spawns a different type (e.g. the rise of the UK's direct action movement) (see Saunders 2007a).

\section{The Case for looking at Organisational Strategy and Status}

3.1 It is not the global concept of political opportunity structures, as expressed by Kitschelt (1986) and Kriesi (1995), that is useful in terms of explaining the interorganisational networking behaviour of environmental organisations, but rather the criticisms of the approach that consider context and contingent factors. Dalton's (1994:171) study of environmental organisations in Western Europe, for instance, concluded that local level factors that shape political opportunities - based on environmental organisations' external identity, ideologies and strategies - were more influential in determining the variety of movement activity within counties than macro-political opportunity factors were at explaining variation between countries. For instance, the lack of political acceptance of the radical environmental group, Earth First! (EF!), is more-or-less consistent across the globe despite different political opportunity structures. Hence political opportunities are perhaps more accurately applied at the organisational level, rather than the movement level, taking into account organisational differences in status, strategy and issues.

3.2 Fortunately, we are not left in a theoretical abyss. The theory of 'insiders and outsiders', derived by scholars of pressure groups, provides a model which can be used to help fine-tune the theory of political opportunities. At the simplest level, environmental organisations can be categorised according to the strategies they use, and the extent to which these strategies reflect archetypal 'insider' or 'outsider' behaviour. Insiders are viewed as legitimate, are widely consulted by the government and have access to the executive, whereas outsiders are those lacking access to the political system (Grant 1989). Grant, however, has been criticised by Whitely and Winyard (1987) for ignoring the differences between status and strategy - status can vary according to the strategy a group is pursuing, and may also depend on the political salience of issues being addressed. For instance, Saunders (2000:74-5) showed how the status of Greenpeace and Friends of the Earth (FoE) varies according to the strategies used and the receptivity of the governmental department involved. The contrasting views of the late Department of Trade and Industry (DTI) (now called the Department of Business Enterprise and Regulatory Reform) and Exports Credit Guarantee Department (ECGD) towards FoE are shown as an example in Table 2. In Example 1, FoE pursued an insider strategy, resulting in favourable treatment from the DTI. In Example 2, it deployed an outsider strategy, challenging the decision to fund the llusi Dam. The ECGD was put on the defensive and outwardly attacked FoE, brandishing it a liar and awarding it contingent outsider status. As well as illuminating the importance of strategy in determining the political opportunities available for challenging groups, this example also illustrates the importance of a more localised conception of political opportunities. Those challenging policy can rely on the receptivity of particular government departments or county / local councils as much as on aggrandised nation-wide political opportunity structures.

Table 2. The Variable Status of FoE

\begin{tabular}{|c|c|c|}
\hline & $\begin{array}{c}\text { Example } 1 \text { : FoE AS } \\
\text { LEGITIMATE }\end{array}$ & $\begin{array}{c}\text { Example } 2: \text { FoE AS } \\
\text { INCRIM } 1 \text { ATE }\end{array}$ \\
\hline Department & DTI & ECGD \\
\hline Quo te from Minister & $\begin{array}{l}\text { "FoE have an extremely important role } \\
\text { to play in helping to shape policy on } \\
\text { environmental issues. I value the } \\
\text { contribution they are making to the } \\
\text { debate on future waste and recycling } \\
\text { measure legislation ... I am determined } \\
\text { to build on the good communication } \\
\text { links that exist between FoE and the } \\
\text { DTT" } \\
\text { Consumer Affairs Minister Nigel } \\
\text { Griffiths, 27 April 1998 (DTI website } \\
\text { 2000) }\end{array}$ & $\begin{array}{l}\text { "Far from being a secretive or clandestine } \\
\text { process, as alleged by FoE, our approach to } \\
\text { the Ilusi Dam project has from the outset } \\
\text { been open and balanced. All the } \\
\text { misinformation involved has flowed from } \\
\text { FoE, who at no point have sought a } \\
\text { meeting with me or my officials" } \\
\text { Minister for Trade, Brian Wilson, } 2 \text { July } \\
1999 \text { (ECGD website 2000) }\end{array}$ \\
\hline
\end{tabular}

Source: Saunders (2000)

3.3 By distinguishing between status and strategy, and appending the additional category of 'thresholder' to describe organisations using a mixture of insider and outsider strategies, like FoE and Greenpeace (as suggested by Baggott 1995), some of the problems associated with over-simplicity of the 'insider/outsider' 
3.4 An ideal-type insider group has a favourable status with the government, has access to the executive and works bureaucratically - in a manner amenable to the polity itself. Its strategy would largely be comprised of negotiations and consultations with ministers and it would deal with small-scale issues already on the policy agenda. It is to this type of organisation that the government, whether local or national, or a particular department, will be most open. At the opposite extreme, ideological outsiders would be met with a closed polity. They would be ideologically opposed to the state and therefore would have unfavourable status. Their strategy would bypass the state - they may be a small group with violent tendencies, or they may be seeking self-directed change. The issues of concern to them would be broad ranging and incompatible with modern bureaucratic polities (Table 3 ).

Table 3 : Implications for environmental movement networking based on strategy and status

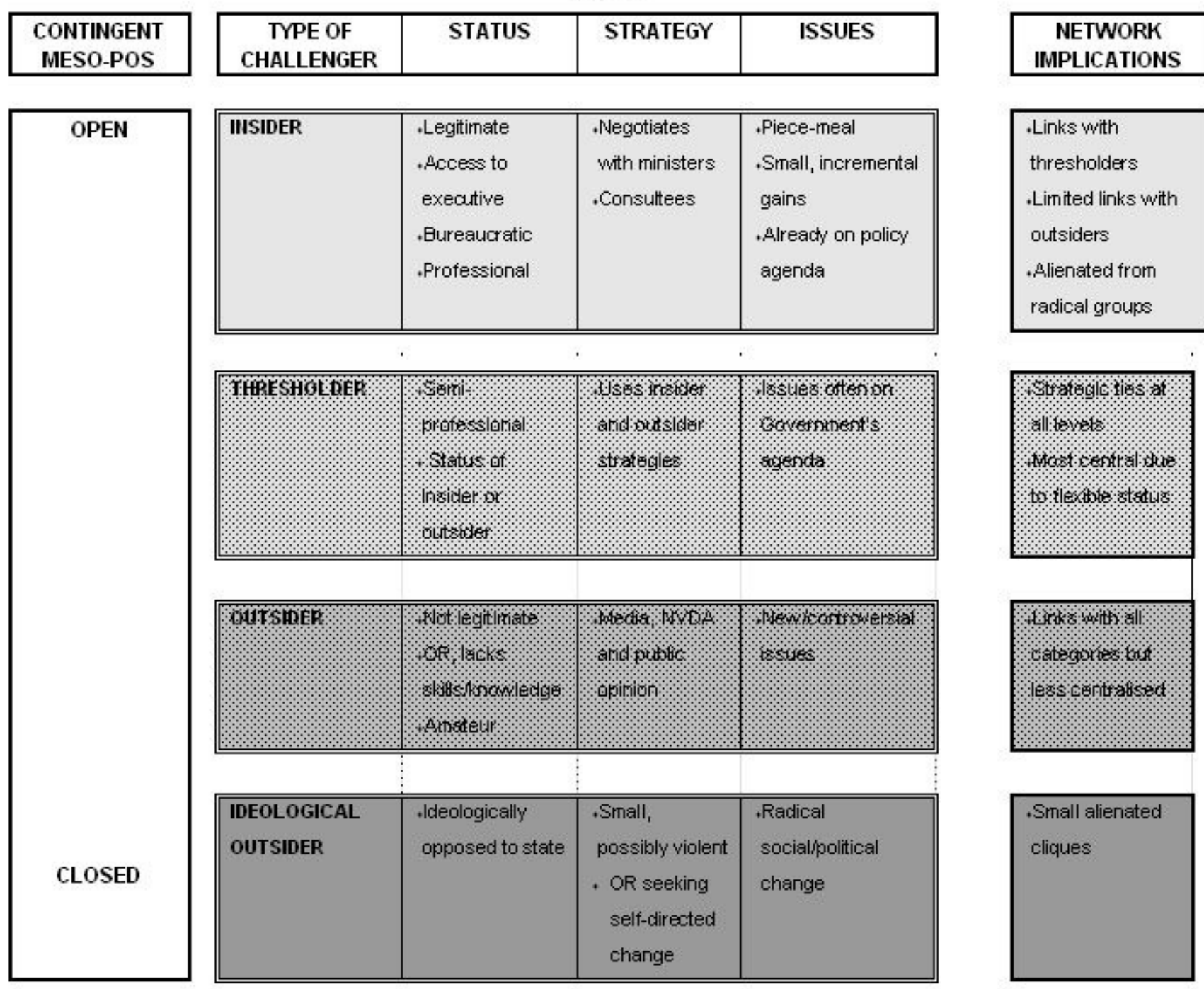

This model is based categories of pressure groups suggested by Grant (1989) and Baggott (1995).

3.5 This approach is useful for showing that groups facing an open political structure as 'insiders' (Grant 1995:18-23) are likely to moderate their tactics. For such groups it becomes important to 'not jeopardize their relationship with government by attacking public policy openly' (Baggott, 1995:10). For this reason, ideological outsiders that regard the state as their adversary, and insiders who deem the state an ally and partner can be expected to dissociate from each other. This theory is reflected in what we already know about the environmental movement. Rawcliffe (1998:17), for example, notes that the Royal Society for the Protection of Birds (RSPB) is an 'insider' environmental organisation, and is therefore unlikely to network with radicals like EF!. Thresholders meeting a relatively inert set of political opportunities can be expected to have the most extensive networks due to their unconstrained status and use of strategies. Greenpeace, for example, which uses mostly thresholder strategies, denies any links with Sea Shepherd, a radical splinter group, so as to not further impair its already controversial reputation and negatively affect its status (Pearce 1991:30-31). Although the presence of a more radical group may be beneficial to Greenpeace through the radical flank effect by making its demands appear more practical and compromising, groups will also be likely to be wary of the 'negative radical flank effect', in which counter-movements or the state tarnish entire movements as deviant (Haines 1988:167). This is likely to have implications for the way in 
which more radical groups are received by the mainstream movement, as well as how the polity reacts to demands from the movement as a whole. We return to test these theoretically informed expectations after an introduction to the methodology.

\section{Methodology}

\section{Atriangulated approach}

4.1 The research employed a triangulated approach, using a mailed questionnaire survey and qualitative interviews with key campaigners at national, regional (London-wide) and local (borough or below) level. The survey was used to gather quantitative information on organisational characteristics and strategies, organisational relationships with national and local polity, and networking between environmental organisations. The survey was followed with qualitative interviews with key campaigners from a selection of different environmental organisations across ideological positions and spatial scales within the environmental movement. The interviews were open-ended and loosely based on the results of the survey. Qualitative material was collected in order to help interpret the networking patterns uncovered by the survey.

\section{The sample for the survey}

5.1 All known national and regional environmental organisations in London and local ones around Greenwich (southeast) and Heathrow Airport (northwest London) were surveyed. Organisations were identified by internet searches and snowballing with key activist informants until saturation point was reached. The network's spatial boundary was Greater London for two main reasons: the vitality of environmental activism in the capital, and because activism there has been under studied. A questionnaire was sent to all identified national and regional environmental organisations within Greater London, as well as to local groups within two locales - the region immediately surrounding Heathrow Airport, and a chunk of southeast London surrounding the Greenwich peninsular. These spatial limits are, indeed, arbitrary; but they were regarded as a necessity to keep a control on the network size, given the time and financial constraints of the research. To be included in the sample, organisations needed to answer in the affirmative to the following two movement boundary questions:

1. Do you consider your organisation to be part of the environmental movement? Yes / No

2. Is your organisation part of a network of environmental organisations? I.e. is your organisation in contact with at least one other organisation that is part of the environmental movement? Yes / No

5.2 Nine (2\%) of the organisational responses did not meet the criteria for inclusion in the sample. In total, of the 440 questionnaires sent, $32 \%$ were returned completed. ${ }^{[1]}$ Surveys were completed by organisational representatives, with one survey being completed for each organisation, each representing an organisational point of view.

\section{Classifying environmental organisations}

6.1 Environmental organisations were classified according to the strategies they claimed to use in their survey responses (see Table 4) and according to their perceived status with local and national governments.

Table 4. Campaigning activities and categorisation of strategies

\begin{tabular}{l|l}
$\begin{array}{l}\text { CATEGORY OF } \\
\text { PROTEST }\end{array}$ & ACTIVITES \\
\hline Insider & $\begin{array}{l}\text { Petitions, leafleting, press conferences, letter writing, researching and } \\
\text { reporting, education and training, government consultee, LA21 } \\
\text { involvement, procedural complaints, litigation, public meetings }\end{array}$ \\
$\begin{array}{l}\text { Thresholder } \\
\text { Outsider }\end{array}$ & $\begin{array}{l}\text { Media stunts, marches, rallies, demonstrations, cultural performances } \\
\text { andior a mixture of insider and outsider activities } \\
\text { Boycotts, distuption of events, blockades/occupations } \\
\text { Mthical shoplitting, ecotage, adbusting } \\
\text { Social events, practical conservation }\end{array}$ \\
\hline
\end{tabular}

6.2 In the questionnaire, environmental organisations ticked one of five possible responses to give an indication of their relationship with local and national government.

1. Positive - the government/council frequently seeks our environmental organisation's advice.

2. Ambivalent - the government/council is friendly, but our environmental organisation generally initiates contact.

3. Contingent - the receptiveness of the government/council is dependent on the issue(s) or 
department(s) involved.

4. Negative - our environmental organisation unsuccessfully attempts to influence the government/council, or has become blacklisted.

5. No relationship - our environmental organisation does not have a relationship with government/council either because we prefer alternative campaign targets or do not work at that level (e.g. local amenity societies are unlikely to have a relationship with national government because much of their work seeks to influence the local council instead). ${ }^{[2]}$

\section{The network}

7.1 The effect of strategies and status upon networking is considered by looking at the collaboration network - the type of networking which Saunders (2007b) suggests demonstrates 'real' movement dynamics. The 'collaboration network' consists of the respondent organisations' answers to the following question:

7.2 Please list the five most important environmental organisations with which your organisation has collaborated on a campaign or environmental activity in the last 12 months.

7.3 This was asked in respect of each of local, regional (London-wide) and national environmental organisations.

\section{Findings}

7.4 This section of the article takes a look at the findings of the survey, and illustrates them with interview quotes as appropriate. It begins by looking at the extent to which organisations that use different types of strategies - as insiders, thresholders and outsiders - co-operate with each other, before turning to consider the extent to which status, as measured by organisations' relationships to local and national government, seems to determine patterns of collaborative networking. The latter sub-section on status is split into two further sub-sections, looking at local and national governance in turn. The discussion of status with each of local and national governments begins with some contextual information gleaned from qualitative interviews, which indicate the variable extent to which environmental activists consider local and national governance to be 'open'. This background information is included because it helps to further demonstrate why broad-brush approaches to political opportunities are sometimes inappropriate, and goes some way to explain why environmental movement organisations have a variety of types of relationship with governance.

\section{Organisational strategies and inter-organisational networking}

8.1 In practice, very few organisations (only three in our sample) are pure outsiders. Even the radical anarchist environmental organisation surveyed engages in occasional lobbying. This means that we are unable to draw particularly concrete conclusions about the behaviour of outsiders. Nonetheless, all of the three collaborative ties that outsider groups admitted to having to other environmental organisations were directed towards thresholder organisations. Of thresholders' 140 ties, $86 \%$ were directed towards other thresholders. This is likely to be because thresholders have similar political viewpoints and strategies; as they are not insiders, they are more likely to be in need of allies and, unlike some radicals, are pragmatic enough to cooperate. Even given the limited number of outsiders in the sample, we have evidence of collaborative ties between thresholders and outsiders. Thresholders, therefore, do have ties traversing the widest spectrum (Table 5). Collaborative ties from insiders to outsiders are missing, but we would not expect questionnaire respondents to admit to dealings with outsiders, at least not the most radical of them. Indeed, previous research has shown collaborative links have existed between radical outsiders and their more moderate counterparts, although the moderate parties are often unwilling to admit so. Seel and Plows (2000:119), for example, noted that 'Greenpeace ... sometimes gives 'under the counter' financial assistance to local EF! groups or particular issue campaigns'. Yet Greenpeace consistently underplays this cooperation.

Table 5. Collaboration network by balance of activities

\begin{tabular}{|l|c|c|c|c|c|c|c|c|}
\hline \multirow{2}{*}{$\begin{array}{c}\text { INITIATORS OF } \\
\text { TIES (i) }\end{array}$} & \multicolumn{8}{|c|}{ RECEIVERS OF TIES (j) } \\
\cline { 2 - 9 } & \multicolumn{2}{|c|}{ Insiders } & \multicolumn{2}{c|}{ Thresholders } & \multicolumn{2}{c|}{ Outsiders } & \multicolumn{2}{c|}{ Total } \\
\cline { 2 - 9 } & $\mathbf{n}$ & $\%$ & $\mathbf{n}$ & $\%$ & $\mathbf{n}$ & $\%$ & $\mathbf{n}$ & $\%$ \\
\hline Insiders & 6 & $26 \%$ & 17 & $65 \%$ & 0 & $0 \%$ & 23 & $100 \%$ \\
Thresholders & 17 & $12 \%$ & 120 & $86 \%$ & 3 & $2 \%$ & 140 & $100 \%$ \\
Outsiders & 0 & $0 \%$ & 3 & $100 \%$ & 0 & $0 \%$ & 3 & $100 \%$ \\
\hline
\end{tabular}


Organisational status, as measured by perceived political relations, and interorganisational networking

\section{Local Borough Councils}

\section{Open or closed?}

9.1 Organisations within the same borough have different perceptions of the openness of local government, demonstrating further why a broad-brush approach to political opportunities is inappropriate. For instance, whilst the Greenwich branch of a national environmental organisation has, at best, a contingent relationship with Greenwich Borough Council [GBC], a local conservation group has a positive one. The coordinator of the Greenwich branch of a national environmental organisation (interview February 2001) claims that 'to be frank, they [GBC] are barking up the wrong tree' and that GPC deprioritise the environment by placing the economic agenda at the heart of decision-making, and view the group as a 'thorn in their side'. In contrast, the conservation organisation has a constructive relationship with GBC. The group coordinator suggested that 'they [GBC] are quite receptive to us, and they know us very well now and they do trust us, which is good to have'. Consequently, the group is considering adopting a more formal partnership (group coordinator interview, September 2003).

9.2 Environmental organisations in northwest London also have contrasting views of the 'openness' of their local authority. In the Borough of Ealing (EBC), the LA21 group claimed that LA21 in Ealing amounted to 'words and not action' as annual pollution reports had not been produced by the council since 1997. This group is clearly dismayed by their local authority's apparent lack of concern for the environment. Yet a local conservation group, has a very cosy relationship with the local council, having won an Ealing Council Green Award for two years running.

\section{Relationships with local polity and impacts on interorganisational networking}

9.3 Sixty-nine organisations that were respondents and a part of the collaboration network ${ }^{[3]}$ commented in $^{3}$ the questionnaire on the relationship they have with their local authority. Fifteen claimed to have a constructive relationship, 20 ambivalent, 13 contingent and 11 had no relationship. Interestingly, not a single organisation claimed a negative relationship. Of the 23 ties initiated by environmental organisations with a constructive relationship to their borough, the majority (44\%) were directed towards organisations that lack a relationship with their local governors and $35 \%$ towards organisations with an ambivalent relationship to them (Table 6). This collaboration network mixes together the national, regional and local groups, which is why such a high proportion of groups are claiming no relationship with their local authority - most national environmental organisations campaign at a higher level.

9.4 These results also mix environmental organisations from across London boroughs. Therefore, especially when collaborative partners are from a different borough, it often matters little how potential allies get on with their own borough because often collaboration will not have any bearing on the other party's relationships with their own borough. Overall, it appears that relationships with local borough councils only seem to make a difference for organisations that campaign at a purely local level.

Table 6. Collaboration network by relationship to local authorities

\begin{tabular}{|c|c|c|c|c|c|c|c|c|c|c|}
\hline \multirow{3}{*}{$\begin{array}{l}\text { INITIATOR } \\
\text { OF TIES (i) }\end{array}$} & \multicolumn{10}{|c|}{ RECEIVER OF TIES (j) } \\
\hline & \multicolumn{2}{|c|}{ Constructive } & \multicolumn{2}{|c|}{ Ambivalent } & \multicolumn{2}{|c|}{ Contingent } & \multicolumn{2}{|c|}{$\begin{array}{c}\text { Non } \\
\text { Existent }\end{array}$} & \multicolumn{2}{|c|}{ Total } \\
\hline & $n$ & $\%$ & $\mathrm{n}$ & $\%$ & $n$ & $\%$ & $n$ & $\%$ & $n$ & $\%$ \\
\hline Constructive & 2 & $9 \%$ & 8 & $35 \%$ & 3 & $13 \%$ & 10 & $44 \%$ & 23 & 100 \\
\hline Ambivalent & 8 & $28 \%$ & 12 & $41 \%$ & 2 & $7 \%$ & 7 & $24 \%$ & 29 & 100 \\
\hline Contingent & 7 & $44 \%$ & 3 & $19 \%$ & 0 & 0 & 6 & $38 \%$ & 16 & 100 \\
\hline Non Existent & 2 & $9 \%$ & 2 & $9 \%$ & 12 & $55 \%$ & 6 & $27 \%$ & 22 & 100 \\
\hline
\end{tabular}

9.5 Although the relationship between an anti-airport expansion group and Hillingdon Borough Council (HBC) is best classified as 'ambivalent' because of HBC's initial reluctance to support the campaign, it is indicative of how an environmental organisation's positive relationship with local government can constrain its activities and network links. HBC has reportedly provided at least $£ 50,000$ for the anti-third runway campaign (Longhurst and Nadel 2002), including the funding of the anti-airport expansion group's road show 
that took to the streets after the after the 2003 aviation White Paper was released. Because the group is dependent upon funding from its local council, it:

can't actually do anything illegal because if we do anything illegal, the council will cut off the money. At the same time, we appreciate the frustration of the people who want to take direct action, but we wouldn't at this stage want them on our committee, purely and simply on the grounds that ... [the group] is funded by the council (Coordinator, anti-airport expansion group] interview February 2004).

9.6 This caused a rift between those who wanted to take direct action, and those sought to abide by council rules. According to a local anti-third runway campaigner (LC):

LC There were some people who really wanted to get up and be a bloody pain in the arse and do things that the airport won't like. But you see the group itself didn't want to, and it split up a bit in that way. I was prepared to be one of those that was militant, but I kept on the ground and I said to the others, 'if you've got anything you want done, like being really militant, I am there with you'. So I tried to keep on both sides a bit.

I What do you mean by being militant then?

LC I mean if they wanted somebody to go and block the airport up, or drive really slowly around, or put posters up or, or just driving around the roads at $5 \mathrm{mph}$ for hours and hours in the morning. (interview, January 2004).

9.7 Although the anti-airport expansion group is somewhat constrained in what it can do as a coalition, this has not stopped its members being highly supportive of direct action. Members have, for example, supported the court cases of direct activists who occupied the construction site of Terminal Five. However, even if the local council did not fund the group, it would probably continue to use conventional insider techniques because this allows for the mediation of a contingency plan should the development go ahead:

If, in the final analysis, we lose, we have got to work with those blighters across the road, we have got to get all sorts of different types of facilities and amenities for the people left ... the association has always been careful to keep the lines of communication open with BAA and people like that ... (anti-airport expansion group coordinator, interview, February 2004).

9.8 National and regional organisations often lack a relationship with their own local borough councils, but if they have local groups, they are able to impact upon local authorities via these rather than through a centrally coordinated effort. For example, a branch of national FoE in north west London claims that national FoE are one of their top five collaborative partners, but national FoE itself has no contact with HBC (the local council) either because of its more national focus or because it 'contracts' this kind of work out to its local group. The highest figure in Table 6 is $55 \%$ and this suggests that organisations lacking a relationship with their local council tend to favour organisations with a contingent relationship as collaborative partners. National organisations may not have relationships with their local councils but may choose local groups as collaborative partners as part of a wider campaign strategy. For instance, in their anti-GM campaign, FoE called upon local FoE groups (that mostly have contingent relationships with their local councils) to engage with their local councils to persuade them to become GM-Free Zones. To date at least half a dozen local authorities have voted for the exclusion of GM crops in their area ${ }^{[4]}$ (FoE 2003a).

9.9 Greenpeace undertook a similar strategy in its Incineration Busters campaign (Summer 2001-Spring 2002). It produced postcards for on-street signing, asking local councils for more emphasis to be placed on the reduction, recycling and composting of waste as an alternative to incineration. Groups of Incinerator Busters were formed throughout the country, consisting mostly of pre-established non-Greenpeace incinerator action groups. Resources and training were provided for local activists. After some long and thoughtful research, Greenpeace drew up a pro forma Zero Waste Strategy. All local activists had to do was to change the details - for example the total amount of waste produced by the local authority, the population size, the nature of local industry - and the result was a Zero Waste ${ }^{[5]}$ Strategy applicable to each district or county where activists took part (Greenpeace 2001). The Zero Waste charter that emerged from the Strategy was the result of wider collaboration involving FoE, Communities Against Toxics and the UK Zero Waste Alliance. In England, one local authority (Bath and North East Somerset) and one county council (Essex) have adopted a Zero Waste policy (Green Party Website 2003).

9.10 These successes are clearly the result of collaborative ties between (national) organisations that lack a relationship with their local council and local organisations that have at least a contingent relationship with them.

\section{Relations with national government}


10.1 Just as with local governance, activists' perceptions of national government vary according to organisational type and issue focus. According to a marine campaigner for a national environmental organisation (interview January 2004):

... The UK government is pretty good from a climate change point of view. [They are] really up for pushing wind power and ... when we did our No Nukes, Yes2Wind campaign, their White Paper changed completely, I mean it was not just us, but they decided that they could go with wind and that it was a viable alternative and that their stance on it was, we were quite surprised at how good it was.

10.2 But, on other issues, including wood procurement - for which the organisation had embarrassed the government by exposing their use of illegally harvested wood from Cameroon to rebuild their Cabinet offices - and GM foods, the government were 'really, really bad'.

10.3 In terms of aviation, the policy arena is viewed as relatively closed by campaigners because the 2003 White Paper left decisions more-or-less in the hands of the aviation industry. In his opening address to the Post White Paper Airport Watch conference, a veteran campaigner told the audience that:

I think something fairly significant has probably happened as to who we will be focussing on post White Paper. We were focussing on government and civil servants because they were drawing up the White Paper ... But Post White Paper I think is different because we know what the government has said, it feels it has done its bit. It is now saying it is up to the aviation industry and developers to come up with proposals ... And it seems to me that the key focuses now of our campaign needs to be on the developers and the banks and the construction companies (veteran campaigner 2004).

10.4 Even prior to the release of the White Paper, anti-airport expansion campaigners were sceptical of the government's stance on aviation. Fawcett's (then Minister for Transport) comment to the Airport Watch Conference in 2001, that 'Blair is committed to sustainable development', was met with raucous laughter from the audience.

10.5 The airport lobby have seemingly convinced the government of the importance of aviation for the economic growth of the country; despite transport expert Professor Whitelegg successfully showing that the green alternatives could bring a greater economic return and more employment (FoE 2003b). According to a prominent member of staff in a key national environmental organisation:

The government is supposed to have green ministers, but they rarely meet, have no weight and aren't reflecting green policies within their departments as they have to deliver on other, often contradictory, policies. Nor are there enough green departments. It is ridiculous having a single department to focus on the environment, which in itself is not green enough. The Department for Trade and Industry, the Department for Transport and the Treasury have few if any environmental and sustainable development concerns and are probably the worst culprits in the government. They are completely ignoring the sustainable development agenda or at best they are seeing sustainable development as a negative anti-progress ideology, which it is not. Either that or they hijack sustainable development so that it ends up meaning all the unsustainable things we are doing now i.e. "sustainable development means building more runways" (interview, January 2004).

10.6 In line with the critique of macro political opportunity structures proffered earlier in the paper, these interview quotes neatly demonstrate that the openness of the government varies according to the organisation involved, the nature of the issue, and the department being targeted, but also according to the perception of individual activists. We now turn to look at how perceived relationships with the national policy impact upon networking among environmental organisations.

\section{Relationships with national polity and impacts on interorganisational networking}

10.7 Of the 59 organisations in the collaboration network that provided an indication of their relationship with national government, six claimed constructive ties, seven ambivalent, eleven contingent, six claimed a negative relationship and 29 said they had no relationship.

10.8 Although $80 \%$ of collaborative ties of organisations with a constructive relationship to the government are with organisations that have a contingent relationship, this is not as meaningful as it might appear, because the six organisations with constructive relations with the government have only a total of five ties directed to other organisations (at least one of them had no ties at all and the others averaged only one tie each), four to contingent ones and one shared with another organisation with a constructive relationship to the government. What this does perhaps indicate, however, is the tendency for those with constructive relationships to work alone - perhaps they have less need to collaborate because they are not, like thresholders, seeking to influence public opinion and generate a groundswell. However, CPRE, which has a 
constructive relationship to the government - 'Ministers never refuse to meet CPRE' - works extensively with organisations with a contingent relationship to the government including FoE (especially on the Planning Campaign) and Transport 2000 (Conder [CPRE], interview with Adams, June 2000). However, CPRE, like other 'insider' organisations is unlikely to be more outrageous than this in its campaign alliances because its constructive relationship makes it feel awkward about criticising government schemes. As a member of staff in an environmental organisation with a constructive relationship with government told us in interview:

You have to tread a very thin line when you have this type of relationship with the Government ... When we are overly critical of their schemes, such as the Deputy Prime Ministers' Sustainable Communities Plan, it doesn't go down too well (member of staff from an insider organisation, December 2003).

10.9 Of the five collaborative ties that organisations with a constructive relationship with the government extend, none of these is to organisations with a negative relationship to the government. Stop Stansted Expansion (SSE), despite fighting a campaign at a critical campaign time, is an example of an organisation that has a constructive relationship with the government but is avoiding collaboration with EF! and EDAGers who have a negative relationship with it. Although some campaigners have attempted to reconcile the differences, SSE remain convinced of the efficacy of insider methods of campaigning. According to a prominent airports campaigner:

I organised a small meeting ... Two or 3 representatives from Stansted, Gatwick and HACAN were invited to talk about direct action. And it was very useful, but there was a bit of a squabble afterwards because ... the people from Stansted ... are wealthy, they are well connected and I think there is still a feeling that they could, because of that ... win through conventional means. They feel that they are part of the establishment - clearly some of them are .... and they feel inclined to talk to people in the establishment on legal grounds, on economic grounds or what have you and they think they can probably win. And therefore, whilst they're not opposed to direct action in principle, they see it as a little bit below themselves (interview January 2004).

10.10 Similarly, an insider organisation felt threatened by a more reformist organisation's involvement in the campaign to prevent dilution of planning laws. A key campaigner from a prominent national environmental organisation has interpreted this clash between the organisations in terms of the insider organisation trying to seeking to preserve its political reputation:

in government circles ..[the insider organisation] is clearly the 'respected voice' and it felt that ... [the other national environmental organisation] was rocking the boat a little by being straight-up and forward about the issues ... [The insider organisation] felt that their cosy relationship with the government may be threatened by the ... [other national organisation's] approach (interview January 2004).

10.11 Along similar lines to the insider wanting to preserve its carefully modelled political reputation, a radical direct action group [EDAG] tactfully decided not to be a formal part of a campaign coalition, which sought for a gas pipeline project to be scrapped, so as not to tar its credibility:

Well, we discussed it within the campaign whether they should be officially part of the campaign and the decision was, that for both the coalition and for ... [EDAG] it would impose restrictions. ... [EDAG] wouldn't be able to behave in the ways they wanted to in terms of any dodgy stuff like office invasions or stuff that might ... run foul of the law. They wanted the freedom of not having to tell us every time they were going to do an action ... obviously because of the way ... [EDAG] works, it is on the spur of the moment and you can't cope with an approvals process on decision-making that takes ages. Partly for purely pragmatic reasons and I guess there is a whole thing about who might be liable for illegal actions (Climate Campaigner for a national environmental organisation, in interview, January 2004).

10.12 In the same vein, whilst a mainstream national environmental organisation had great sympathy and admiration for the anti-capitalist demonstration in Seattle in 1999, reportedly, '[the director] was really impressed by Seattle because it was such a broad range of people out in the streets', it will not 'touch May Day [anti-capitalist demonstrations in London] with a barge pole' despite the fact that the organisation has become:

very interested in anti-capitalist/globalisation ... issue. In fact that has been the basis of some of our big campaigns. I mean ... [our organisation] are of course very wary of throwing rocks at windows and getting lots of police out and any of that sort of thing, and as a big organisation, I think they have to be (member of staff, in interview, February 2004). 
Table 7. Collaboration network by relationship to national government

\begin{tabular}{|l|c|c|c|c|c|c|c|c|c|c|c|c|}
\hline \multirow{2}{*}{$\begin{array}{l}\text { INITIATOR } \\
\text { OF TIES (i) }\end{array}$} & \multicolumn{10}{|c|}{ RECEIVER OF TIES (j) } \\
\cline { 2 - 13 } & \multicolumn{2}{|c|}{ Constructive } & \multicolumn{1}{|c|}{ Ambivalent } & \multicolumn{2}{|c|}{ Contingent } & \multicolumn{2}{|c|}{ Negative } & \multicolumn{2}{|c|}{$\begin{array}{c}\text { Non } \\
\text { Existent }\end{array}$} & \multicolumn{3}{|c|}{ Total } \\
& No. & $\%$ & No. & $\%$ & No. & $\%$ & No. & $\%$ & No. & $\%$ & No. & $\%$ \\
\hline Constructive & 1 & $20 \%$ & 0 & $0 \%$ & 4 & $80 \%$ & 0 & $0 \%$ & 0 & $0 \%$ & 5 & 100 \\
Ambivalent & 1 & $13 \%$ & 2 & $25 \%$ & 3 & $38 \%$ & 0 & $0 \%$ & 2 & $25 \%$ & 8 & 100 \\
Contingent & 6 & $22 \%$ & 2 & $7 \%$ & 13 & $48 \%$ & 3 & $11 \%$ & 3 & $11 \%$ & 27 & 100 \\
Ilegative & 1 & $10 \%$ & 1 & $10 \%$ & 5 & $50 \%$ & 0 & $0 \%$ & 3 & $30 \%$ & 10 & N/A \\
Ilon Existent & 0 & $0 \%$ & 1 & $3 \%$ & 9 & $29 \%$ & 0 & $0 \%$ & 21 & $68 \%$ & 31 & 100 \\
\hline
\end{tabular}

10.13 The presence of 27 collaborative ties amongst the 11 organisations with a contingent relationship to the government further confirms that organisations with a flexible approach in their dealings with the government have extensive interorganisational linkages. Perhaps they have a greater need to collaborate in their quest to generate a groundswell or be persuasive. Organisations with a constructive relationship that engage mostly in insider strategies do not need much assistance because they may not be applying pressure so much as responding to a request from the government (Table 6).

10.14 Organisations with a contingent relationship to government have most of their ties directed towards other organisations like themselves. This may be because the contingency of their relationship with the government is a result of their range of insider and outsider campaigning strategies. Organisations with a contingent relationship are likely to be multi-issue, and therefore have more scope for collaborating. For example, as a multi-issue organisation, FoE co-operates with Stop Esso, the Campaign Against Climate Change and EDAG on climate change, and WWF and Greenpeace on Yes2Wind and Greenpeace on GM (The Five Year Freeze). In addition, each campaign team has a multitude of additional linkages besides these informal coalitions. If it were a single-issue organisation, it would likely only co-operate with one of those groups of partners.

10.15 Whilst only six organisations claimed a negative relationship with the government, there are actually 11 ties between these organisations and groups with different configurations of relationships. But most of the links that such organisations have are directed towards organisations that have a contingent relationship to government. It may be that contingent organisations make good allies when they are campaigning with organisations that have a negative relationship with the government on issues that the government is failing to address, and this is likely to be when outsider strategies are most appropriate and most popular.

10.16 The only striking relationship that organisations with an ambivalent relationship to the government have is with those with a negative relationship to the government. A quarter of their collaborative ties are directed towards organisations lacking government recognition, or preferring to campaign in different ways (Table 6).

10.17 Amongst organisations lacking a relationship with the government, $68 \%$ of their collaborative connections are to other organisations like themselves. This is a meaningful percentage because there are 31 ties in this category - a little over one per organisation. This is largely because of their local focus - of the 66 organisations that claimed to have no relationship with the government, all but 16 were local. Others were internationally focused conservation organisations like Save the Rhino and Rainforest Concern and regional reformist or conservation organisations (London FoE and London Wildlife Trust), and radical information processing organisations (e.g. Green Anarchist, Platform). There is, however, a high degree of collaboration between organisations with a constructive and contingent relationship to government. This is likely to be at its highest when those with a contingent relationship to the government are on favourable terms with a certain department, or are campaigning on relatively non-controversial issues.

\section{Conclusion}

11.1 This article has demonstrated the problems that arise in comparative cross-national studies of political opportunity structures due to conflation of structures and contingent political variables, and the difficulty of prioritising and operationalising these concepts. This is not, however, to be totally dismissive of the broadbrush approach to political opportunity structures. Clearly a polity that represses all protest movements will create movements much more sect-like and underground than in one which welcomes them. 
11.2 However, as we have demonstrated, structural variables alone would wrongly predict that Britain's environmental movement be moderate, given the relative ease with which such groups are able to make their representations heard (Rootes 1992). Although this is true for some environmental organisations, others are much more radical than the broad-brush approach would allow for. Generally speaking, when comparing environmental organisations within a country, it seems to make more sense to consider political opportunities as based on strategies and status rather than on structures, or other features of the polity.

11.3 In the environmental movement, we have shown that, as predicted by theory, thresholders have the widest variety of ties across the insider-outsider continuum. Insiders and outsiders widely collaborate with thresholders. This however is partly due to the skew in the data towards thresholders (most respondents were thresholders).

11.4 The anti-airport expansion group provides a textbook example of a local insider being constrained in its relations with outsiders due to fear that it will lose its income and status should it deviate from legal means or be associated with criminal activity. Similarly a national insider, was wary about taking an aggressive stance in its campaigning and so was concerned with another national environmental organisation's direct approach in the campaign to revoke the Planning Bill. Although the 'insider' organisation has quite extensive network links, most organisations that have a constructive relationship with the government tend to work in relative isolation. This could be because they work on tightly defined specialist tasks, or because they perceive it as safer to work alone as they are concerned about losing the status they have achieved. Thus, the finding that organisations with a constructive relationship to the government hardly ever chose those with a non-existent or negative relationship as collaborators is congruent with the insider-outsider theory.

11.5 In contrast, organisations with a contingent relationship collaborate with one another to a much greater extent. This is because they have less need to be concerned about their reputation, which is flexible and issue/strategy-dependent or because their multi-issue focus makes them more likely collaborative partners on a wider range of campaigns. FoE, for instance, has consultative status on waste issues and collaborates mostly with insider agencies, but has a radical agenda on 'corporates' with ideological (if not actual) links with the more radical anti-capitalist agenda. When outsiders collaborate with organisations with a contingent relationship to government, this is likely to be on issues that the government is failing to address, or which have become critical (Saunders 2007a). Organisations with an ambivalent relationship to the government appear to sit on the fence, and are in a position to keep radicals relatively content whilst maintaining a semi-cosy relationship with the government.

11.6 This article has also raised several important lessons to be considered in future theorising and empirical research on social movements. Perhaps the biggest lesson this research has taught us is that it is wrong to view social movements as homogenous entities. Instead, they consist of a broad range of organisations, with varying structures, strategies and choices of issues. Whilst cross-national comparisons of political opportunities might be able to enlighten us about the very general nature of social movements within certain countries, they have been unable to tell us anything much about the reasons for the existence of different types of groups within particular movements. This is a commonly made mistake, rooted partly in the misconceived idea that social movement organisations share a collective identity. Instead of a collective identity - a common framework for developing meanings and producing actions organisations within a movement share much more broadly conceived concerns. Their preferred ways and means of addressing these concerns vary considerably, as do their organisational identities (see Saunders 2007c). This, in turn, affects the key movement dynamic of networking which may help achieve or scupper movement aims and thus becomes part of each movement organisation's strategy.

11.7 To properly understand a movement, then, it is necessary to look at networking, not only because it is part of a movement organisation's strategy, but also because it is a key defining feature of social movements. But macro approaches to political opportunities routinely fail to enlighten us about the nature of the networking, which can at least partly be explained by reference to the range of strategies and status of organisations. To resolve this missing piece in the theory of political opportunities, the theory of insiders and outsiders could be applied more broadly as a useful model to use to help appreciate how and why different movement organisations behave in a variety of ways and network with one another to varying degrees. Whilst it may be true that 'building coalitions is high on the list [of movement priorities] - activists need to work cooperatively rather than engaging in turf wars of worrying about who is going to get credit' (Klein 2007, paragraph 6.3), forming coalitions, or collaborative ties is a more complex business than Klein (2007) implies - one which requires a great deal of strategising.

11.8 There is no reason why this more fine-tuned approach cannot be applied to comparisons of social movements in different countries. Contrary to what macro political indicators would lead us to believe, we might find that a relatively open political culture such as Switzerland has some social movement organisations that are ideological outsiders - perhaps anarchists. Whilst macro-political opportunity indicators (both structural and contingent) might be able to explain why such groups are a minority in Swiss movements, they cannot easily account for their emergence, their radical ideologies or the degree to which they are networked into the movement. Thus, looking at strategy and status is essential. It would, therefore, be fascinating to see the work of Kitschelt (1986) and Kriesi (1995) extended to incorporate an attempt to 
explain, using the theory of insiders and outsiders, the different configurations of organisations within a movement, or even several movements, across countries, and to use it to seek to understand the nature of their interorganisational networking.

11.9 However, some more fine-tuning first be necessary. Movements, particularly the environmental movement, focus on a range of issues, some of which are more warmly welcomed by the government than others. So, instead of looking at entire movements, it may, because of the difference that issues make to receptivity by campaign targets, be better to focus on the organisations involved in a single campaign on a particular issue. And secondly, instead of looking just at governance as a target, it would be an interesting exercise to focus on other targets. For example, what effect does the type of relationship that environmental organisations have with corporations have on their status, strategies and networking patterns? Furthermore, we could take a leaf out of Melucci's book and begin to turn towards understanding 'cultural opportunities' (Melucci 1985) so much as political ones; never forgetting, of course, that movements are rarely, if ever, homogenous entities.

\section{Notes}

${ }^{1}$ This figure excludes the $2 \%$ that were returned with negative responses to at least one of the two boundary questions. A further $4 \%$ were returned unanswered, some with a message informing me that the organisation had folded, others claiming that the organisation was unknown at the address to which the questionnaire had been posted. This is to be expected given the nature of collective action. As Knoke (1990) suggests, the environmental movement, especially at the grassroots level, is known to experience periodic attrition and renewal as organisations fold when issues are resolved or activists 'burn out', and new ones form to cover new issues or take their place. Although it seems low, this response rate is not drastically lower than the expected average response rate of $50 \%$ for SMO surveys (Klandermans and Smith 2002), and Ansell's (2003) response rate for a similar survey of US Environmental organisations $(40 \%)$. However, not all respondents provided data on their network links. In all, 114 listed their five most important links with other environmental organisations at each of the national, London-wide and local (borough) levels. Because the data are explored relationally, there is no danger of misrepresenting the structure of the network (see Saunders 2007b).

${ }^{2}$ The labels (emboldened) were not displayed in the questionnaire

${ }^{3}$ Isolated organisations were excluded from the analysis because, by not being part of the network, they are not considered to be a part of the movement (see Saunders 2007b)

${ }^{4}$ In 2003, twelve local authorities had signed up. These are Cornwall, Somerset, South Somerset, South Gloucestershire, Shropshire, Cumbria, Warwickshire, Rydale, South Hams, York, East Riding and the Lake District National Parks Authority

${ }^{5}$ Zero Waste is the idea that all rubbish be ultimately reused, recycled or composted so that working landfill sites and incinerators along with their associated environmental problems become a thing of the past. The Green Party suggest a target of 2020 for Zero Waste to become a reality.

\section{Acknowledgements}

This article is based on PhD research funded by the ESRC. Thanks to Christopher Rootes and Christopher Pickvance for their help in shaping a much earlier version of this paper (when it was a PhD chapter), and to the referees whose comments helped me considerably improve its structure and flow.

\section{References}

ANSELL, Christopher (2003) 'Community embeddedness and collaborative governance in the San Francisco Bay Area environmental movement', in M. Diani and D. McAdam (Eds), Social Movements and Networks: Relational Approaches to Collective Action, Oxford: Oxford University Press, 122-144.

BAGGOTT, Rob (1995) Pressure Groups Today, Manchester: Manchester University Press.

BORDREAU, Vincent (1996) 'Northern Theory, Southern Protest : Opportunity Structure Analysis in Cross National Perspective', Mobilization, 1, No.2: 175-189.

BURSTEIN P, R.L. EINWOHNER and J.A. HOLLANDER (1995) 'The Success if Political Movements: A Bargaining Perspective, in J.C. Jenkins and B. Klandermans (eds) The Politics of Social Protest: Comparative Perspectives on States and Social Movements, London: UCL Press, 275-296.

DALTON, Russell J. (1994) The Green Rainbow, Environmental Groups in Western Europe, New Haven, 
Yale University Press.

DELLA PORTA, Donatella (1995) Social Movements, Political Violence \& the State, Cambridge University Press.

DELLA PORTA, Donatella and Olivier FILLIEULE (2004) 'Policing social protest', in D.A. Snow, S. Soule and H.P. Kriesi (eds), The Blackwell Companion to Social Movements, 217-241.

DIANI Mario (1992) 'The Concept of a Social Movement', The Sociological Review 40, no. 1: 1-25.

DIANI, Mario and Ron EYERMAN (1992) 'The Study of Collective Action, Introductory Remarks' in M.Diani and R. Eyerman, Studying Collective Action, London: Sage, 1-21.

FRIENDS OF THE EARTH (2003A) Local authorities can still apply for GM Zones, at <http://www.foe.co.uk/resource/press_releases/local_authorities_can_stil.html>, last accessed January 2009.

FRIENDS OF THE EARTH, 2003b, Airline congestion charge could give £9 billion, press release, (received via email), dated $16^{\text {th }}$ December 2003.

GAMSON William (1975) The Strategy of Social Protest, London: Dorsey.

GOODWIN Jeff and James M. JASPER (1999), 'Caught in a winding, snarling vine: the structural bias of political process theory', Sociological Forum, 14, no.1: 27-54.

GOODWIN, Jeff and James M. JASPER (Eds) (2003) Rethinking Social Movements: Structure, Meaning and Emotion, Lanham MD: Rowman and Littlefield.

GRANT, Wyn (1989) Pressure Groups, Politics and Democracy in Britain, Philip Allan.

GRANT, Wyn (1995) Pressure Groups, Politics and Democracy in Britain, Harvester, Wheatsheaf.

GREENPEACE (2001) Zero Waste Strategy, London: Greenpeace.

HAINES Herbert (1988) Black Radicals and the Civil Rights Mainstream, 1954-1970, Knoxville, University of Tennessee Press.

KITSCHELT Herbert P. (1986) 'Political Opportunity Structures \& Political Protest: Anti-nuclear Movements in Four Democracies, British Journal of Political Science, No.16: 57-85.

KLANDERMANS, Bert and Jackie SMITH (2002) 'Survey Research: A Case for Comparative Designs', in B. Klandermans and S. Staggenborg, Methods of Social movement Research, London: University of Minnesota Press, 3-31.

KLEIN, Ross, A. (2007) 'The Politics of Environmental Activism: A Case Study of the Cruise Industry and the Environmental Movement', Sociological Research Online, 12, no.2,

<http://www.socresonline.org.uk/12/2/klein.html>.

KNOKE, David (1990) Political Networks: The Structural Perspective, Cambridge University Press.

KRIESI, Hans Peter (1995) 'The Political Opportunity Structure of New Social Movements: Its Impact on their Mobilization' in J.C. Jenkins and B. Klandermans, The Politics of Social Protest : Comparative Perspectives on States and Social Movements, London: UCL Press, 167-198.

LENTIN, Alana (1999) 'Structure, Strategy, Sustainability: What Future for New Social Movement Theory? Sociological Research Online, 4, no.6: <http://www.socresonline.org.uk/socresonline/4/3/lentin.html>.

LIPSKY, Michael (Ed) (1970) Law and Order, Police Encounters, New York, Aldrine Publishers.

LONGHURST C and NADEL R (2002) 'Campaigners' anger boils over at meeting: Furious protesters silence councillors', Uxbridge \& West Drayton Gazette, October $2^{\text {nd }} 2002: 6$.

MAGUIRE Diarmuid (1995) 'Opposition Movements and Opposition Parties :Equal Partners or Dependent Relations in the Struggle for Power Reform', in J.C. Jenkins and B. Klandermans, The Politics of Social Protest : Comparative perspectives on States and Social Movements, London, UCL Press, 199-228.

MCADAM, Doug (1982) Political Process and the Development of Black Insurgency 1930-1970 ., Chicago, Chicago University Press.

MELUCCI, Alberto (1985) 'The Symbolic Challenge of Contemporary Movements', Social Research, 52, no.4: 789-816. 
MEYER and STAGGENBORG (1996) 1996, 'Movements, Counter-movements and the Structure of Political Opportunities' American Journal of Sociology, 101 (6), 1628-1660.

PEARCE, Fred (1991) Green Warriors, MacKays of Chatham PLC, Kent.

RAWCLIFFE, Peter (1998) Environmental Pressure Groups in Transition, Manchester University Press.

ROOTES Christopher (1992) 'The New Politics and The New Social Movements, Accounting for British Exceptionalism', European Journal of Political Research, 22, 171-192.

ROOTES, Christopher (1997) 'Shaping Collective Action: Structure, Contingency and Knowledge' in R. Edmondson (Ed), The Political Context of Collective Action, Power Argumentation and the State , 81-94

ROOTES Christopher (1998) 'Political Opportunity Structures, Promise, Problems and Prospects', La Lettre de la Maison Française, 10, Michaelmas-Hilary, 75-97

SAUNDERS, Clare (2000) Environmental Pressure Groups and Campaigning: Lessons Learned and Future Prospects, unpublished MSc dissertation, University of Southampton, September 2000.

SAUNDERS, Clare (2007a) 'Comparing Environmental Movements in Periods of Latency and Visibility', Graduate Journal of Social Science , 4, no.1: 109-139.

SAUNDERS (2007b) 'Using Social Network Analysis to Explore Social Movements: A Relational Approach', Social Movement Studies, 6, no.3: 227-243.

SAUNDERS, C. (2007c) 'Double Edged Swords? Collective Identity and Solidarity in the Environment Movement', British Journal of Sociology, 59, no.2: 227-253.

SEEL, Ben and Alexandra PLOWS (2000) 'Coming Live \& Direct, Strategies of EF!', in B. Seel, M. Paterson and B. Doherty, Direct Action in British Environmentalism, London, Routledge, 112-132.

STEWART, John (2004), Address to the post-White Paper aviation campaigners' conference, $22^{\text {nd }}$ January 2004.

TARROW, Sydney (1998) Power in Movement: Social Movements and Contentious Politics, Cambridge: Cambridge University Press.

WALLS, John (2002) 'The Campaign Against 'Live Exports' in the UK: Animal Protectionism, the Stigmatisation of Place and the Language of Moral Outrage', Sociological Research Online, 7, no.1, $<$ http://www.socresonline.org.uk/7/1/walls.html>.

WELSH, lan (2001) 'Anti-nuclear Movements: Failed Projects or Heralds of a Direct Action Milieu?' Sociological Research Online, 6, no.3, <http://www.socresonline.org.uk/6/3/welsh.html>.

WHITELY, Paul and Steve WINYARD (1987) Pressure for the. Poor: The Poverty Lobby and Policy Making. London: Methuen. 